\title{
Internacjonalizacja przedsiębiorstwa poprzez franczyzę na przykładzie Yves Rocher
}

\author{
Alina JAMRÓZ-LiGĘZA
}

\begin{abstract}
Artykuł ukazuje franczyzę jako formę internacjonalizacji przedsiębiorstw na przykładzie francuskiego przedsiębiorstwa kosmetycznego Yves Rocher. W części teoretycznej artykułu przedstawiono formy i rodzaje internacjonalizacji przedsiębiorstw oraz scharakteryzowano podstawowe założenia systemu franczyzowego. Główną formą wypowiedzi zastosowaną $\mathrm{w}$ tej części artykułu jest streszczenie. Jest to forma wypowiedzi zapewniająca literalny przekaz podstawowych treści zawartych w tekstach źródłowych. W części empirycznej pracy dokonana została syntetyczna analiza koncernu Yves Rocher, wynikająca z toku prowadzonych rozważań teoretycznych dotyczących systemu franczyzowego.
\end{abstract}

Słowa kluczowe: franczyza, internacjonalizacja, Yves Rocher.

\section{Wstęp}

Celem niniejszego artykułu jest przedstawienie franczyzy jako formy internacjonalizacji przedsiębiorstw na przykładzie francuskiego przedsiębiorstwa kosmetycznego Yves Rocher. Na potrzeby artykułu przyjęto hipotezę, że w przypadku grupy Yves Rocher mamy do czynienia $z$ franczyzą globalną.

W części teoretycznej artykułu przedstawiono formy internacjonalizacji przedsiębiorstw oraz scharakteryzowano podstawowe założenia systemu franczyzowego. Główną formą wypowiedzi zastosowaną w tej części artykułu jest streszczenie. Jest to forma wypowiedzi zapewniająca literalny przekaz podstawowych treści zawartych w tekstach źródłowych. W części empirycznej pracy przeprowadzono syntetyczną analizę przedsiębiorstwa Yves Rocher, wynikającą z toku prowadzonych rozważań teoretycznych dotyczących systemu franczyzowego. 
Przy pisaniu artykułu posłużono się analizą źródeł wtórnych oraz informacjami dostępnymi na stronach WWW. Jeżeli chodzi o źródła internetowe, to polskojęzycznych oraz anglojęzycznych stron dotyczących tematu jest wiele. Podstawowe informacje o przedsiębiorstwie zaczerpnięto ze strony http://www. yves-rocher.pl.

\section{Formy internacjonalizacji przedsiębiorstw}

Pojęcie internacjonalizacji jest związane $\mathrm{z}$ podejmowaniem działalności przez przedsiębiorstwa na rykach zagranicznych. Internacjonalizacja jest stymulowana poprzez dynamiczny rozwój sieci różnego rodzaju powiązań przedsiębiorstw w skali międzynarodowej. J. Rymarczyk określa internacjonalizację jako proces, przez który przechodzi przedsiębiorstwo w swym rozwoju od narodowego, przez międzynarodowe aż do globalnego (Rymarczyk, 1996, s. 18-19). M. K. Nowakowski definiuje internacjonalizację jako „proces, poprzez który firmy zwiększają swoją świadomość co do wpływu działalności międzynarodowej na ich przyszły rozwój, a także ustalają międzynarodowe związki i zawierają transakcje z firmami z innych krajów" (Nowakowski, 1999, s. 20).

Każde przedsiębiorstwo, którego działalność wiąże się z przekraczaniem granic, według C. Lovelocka i G. Yipa, może słusznie utrzymywać, że ma międzynarodowy charakter (Rymarczyk, 1996, s. 435). Każde przedsiębiorstwo międzynarodowe posiada i kontroluje jednostki gospodarcze w dwóch lub więcej krajach. Stąd wydaje się słuszny podział metod międzynarodowej ekspansji przedsiębiorstwa zastosowany przez J. Rymarczyka, który dzieli je na (Rymarczyk, 1996, s. 114):

- eksport,

- licencjonowane,

- franczyzę,

- joint-venture,

- filie zagraniczną,

- zakład produkcyjny,

- spółkę córkę.

Reasumując, internacjonalizacja przedsiębiorstwa to proces umiędzynarodowienia jego działalności, czyli realizacja strategii rozwoju poza granicami macierzystego kraju firmy. Jest to proces włączania się przedsiębiorstwa w działalność gospodarczą poza krajem macierzystym. 


\section{Franczyza jako jedna $z$ form internacjonalizacji przedsiębiorstw}

Definicji franczyzy w literaturze przedmiotu jest wiele. Europejski Kodeks Franczyzy definiuje ją jako „system sprzedaży towarów, usług lub technologii, który jest oparty na ścisłej i ciągłej współpracy pomiędzy prawnie i finansowo odrębnymi i niezależnymi przedsiębiorstwami, franczyzodawcą (ang. franchisor) i jego indywidualnymi franczyzobiorcami (ang. franchisee) (Ziółkowska, 2010, s. 24). Przedsiębiorstwo, które tworzy sieć dystrybucyjną na terenie danego kraju wprowadzając do niej inne przedsiębiorstwa i pozwalając równocześnie na korzystanie $z$ dóbr niematerialnych jest nazywany franczyzerem lub franczyzodawcą, natomiast przedsiębiorstwo, które działa w sieci franczyzodawcy jest nazywane franczyzobiorcą. G. Kolarski ukazuje franczyzę jako metodę prowadzenia działalności gospodarczej w zakresie dystrybucji towarów i usług polegającą na tym, że przedsiębiorstwo otrzymuje prawo do oferowania i sprzedaży określonych towarów i usług w ramach systemu marketingowego innego przedsiębiorstwa i z wykorzystaniem nazwy, znaków towarowych i doświadczeń techniczno-organizacyjnych tegoż przedsiębiorstwa (Kolarski, 1992). Według M. Mendelsohna i D. Achesona franczyza to „udzielenie przez jedną osobę (franczyzera, franczyzodawcy) drugiej osobie (franczyzantowi, franczyzobiorcy) zezwolenia, które upoważnia franczyzanta do prowadzania działalności handlowej pod znakiem towarowym/nazwą firmową franczyzera oraz wykorzystania całego pakietu zawierającego wszystkie elementy niezbędne do tego, aby nie przeszkolona wcześniej osoba mogła być wprowadzona do przedsiębiorstwa zaprojektowanego i utworzonego przez franczyzera oraz by mogła prowadzić to przedsiębiorstwo przy stałej pomocy na z góry ustalonych zasadach" (Mendelsohn, Acheson, 1992, s. 9).

W szerokim znaczeniu franczyzę, czyli tzw. kooperację niekapitałową, należy traktować jako koncepcję rozwoju przedsiębiorczości zakładającą aktywny udział dwóch stron umowy franczyzowej, a mianowicie przedsiębiorstwa udostępniającego swoją wiedzę, sposób działania, markę oraz przedsiębiorcy, który otrzymawszy od franczyzera know-how zobowiązuje się do działania według pewnych zasad określonych w umowie franczyzowej. Podstawowymi elementami systemu franczyzowego są: franczyzodawca, franczyzobiorca, umowa franczyzowa oraz opłata franczyzowa. Charakterystykę składowych systemu franczyzowego zawiera tabela 1.

Franczyza jest metodą bezkapitałowego rozwoju rynku, która uważana jest za jeden z najskuteczniejszych sposobów opanowania określonych segmentów rynku i rozwoju gospodarki (Ziółkowska, 2010, s. 23). Specyfika porozumienia pomiędzy 
franczyzobiorcą a franczyzodawcą stawia przedsiębiorstwa franczyzowe w lepszej sytuacji w stosunku do przedsiębiorstw prowadzących niezależną działalność ukierunkowaną na rynki lokalne. Dla franczyzobiorców konkurencja ze strony przedsiębiorstw międzynarodowych teoretycznie nie powinna stanowić bezpośredniego zagrożenia. Franczyzodawca kontroluje rozwój produktu oraz inwestuje w badania i rozwój $(B+R)$, tak aby oferowane w ramach systemu franczyzowego dobra były konkurencyjne i zaspokajały zmieniające się potrzeby konsumentów (Steinerowska-Streb, 2003).

Tabela 1. Podstawowe elementy systemu franczyzowego

\begin{tabular}{|l|l|}
\hline Franczyzodawca & $\begin{array}{l}\text { Przedsiębiorstwo mające określoną wartość i koncepcję, będące } \\
\text { przedmiotem franczyzy, czyli jedną ze stron współpracy, } \\
\text { koncepcja franczyzodawcy obejmuje sposób prowadzenia systemu } \\
\text { franczyzowego, procedury, standardy, szczegółowe rozwiązania } \\
\text { organizacyjne, know- how oraz markę i znak towarowy firmy. }\end{array}$ \\
\hline Franczyzobiorca & $\begin{array}{l}\text { Druga strona współpracy, która w oparciu o koncept przekazany } \\
\text { przez dawcę systemu, prowadzi własną jednostkę franczyzową; } \\
\text { oferuje franczyzodawcy przede wszystkim swoją przedsiębiorczość } \\
\text { i inicjatywę, znajomość lokalnych uwarunkowan oraz zorientowanie } \\
\text { na sukces przedsięwzięcia. }\end{array}$ \\
\hline Umowa franczyzowa & $\begin{array}{l}\text { Podstawowy element franczyzy określający szczegółowe warunki } \\
\text { współpracy pomiędzy franczyzodawcą a franczyzobiorcą, w tym: } \\
\text { procedury działalności usługowej, produkcyjnej, marki firm, know-how } \\
\text { oraz zasady organizacyjne. }\end{array}$ \\
\hline Opłata franczyzowa & $\begin{array}{l}\text { Pobierana za udzielenie zezwolenia i korzystanie z pakietu } \\
\text { franczyzowego, kluczowy element współpracy franczyzowej. }\end{array}$ \\
\hline
\end{tabular}

Źródło: opracowanie własne na podstawie: Ziółkowska (2010, s. 30).

W tabeli 2 przedstawiono system franczyzowy, biorąc pod uwagę zakres własności, zaangażowania zasobów, stopień ryzyka i stopień jej integracji.

Tabela 2. Cechy charakterystyczne systemu franczyzowego

\begin{tabular}{|l|l|l|l|l|}
\hline Zakres własności & Stopień integracji & $\begin{array}{c}\text { Zaangażowanie } \\
\text { zasobów }\end{array}$ & Stopień ryzyka & Zakres kontroli \\
\hline nie występuje & niewielki & nie występuje & niewielki & wspólna kontrola \\
\hline
\end{tabular}

Źródło: opracowanie własne na podstawie: Rymarczyk (1996, s. 438).

Spośród kilku typologii franczyzy, najbardziej znaczący jest podział ze względu na zasięg działania. I tak, wyróżniamy franczyzę krajową, franczyzę międzynarodową oraz franczyzę typu inbound oraz outbound (Ziółkowska, 2010, 
s. 32). Franczyza krajowa/lokalna wiąże umową franczyzową podmioty gospodarcze, które prowadzą działalność franczyzową na terenie tego samego kraju. We franczyzie międzynarodowej podmioty gospodarcze związane umową franczyzową działają na obszarze innego kraju niż przedsiębiorstwo franczyzodawcy. W sytuacji, kiedy powiązania franczyzowe pomiędzy podmiotami gospodarczymi obejmują wiele krajów lub nawet kontynentów, a nie tylko dwa kraje, mówimy o franczyzie globalnej, będącej rozszerzoną formą franczyzy międzynarodowej. Franczyza typu inbound to system wchodzący, który jest importowany na teren danego kraju, natomiast franczyza typu outbound to łańcuchy powiązań franczyzowych wychodzące z danego kraju (Ziółkowska, 2010, s. 42).

Przedsiębiorstwo decydując się na wejście na rynek zagraniczny poprzez franczyzę musi wybrać jedną z jej form. Do współczesnych form franczyzy należą (Mendelsohn, Acheson 1992, s. 127-136):

- sieć punktów stanowiących wyłączna własność firmy - franczyzer decyduje się nie udzielać zezwolenia na danym terenie i założyć tam własną sieć punktów;

- franchising bezpośredni - franczyzer zawiera umowę franczyzową z każdym franczyzantem indywidualnie i zobowiązany jest zapewnić bazę do uruchomienia przedsięwzięcia oraz stałe wsparcie dla dalszych działań;

- filie - franczyzer prowadzi bezpośrednio działalność na danym terenie, a zadaniem filii jest obsługa sieci punktów franczyzowych lub franczyzer zakłada filię jako bazę regionalną, która ma obsługiwać franczyzantów na danym terenie;

- przedsiębiorstwo kontrolowane - może być związane ze wspólnikiem w ramach joint-venture oraz może być wykorzystywane jako baza regionalna obsługująca subfranczyzantów ${ }^{1}$, bądź subfranczyzantów na danym terenie;

- generalna umowa franczyzowa - subfranczyzer będzie miał prawo otworzyć własne punkty, prowadzić subfranczyzing ${ }^{2}$ lub realizować obie te formy jednocześnie;

- joint venture - firma join venture staje się subfranczyzerem systemu franczyzera. M. Mendelsohn i D. Acheson wprowadzili pojęcie formuły przedsiębiorstwa, na którą składają się: kompletna koncepcja przedsiębiorstwa, proces wprowadzenia i szkolenia we wszystkich aspektach prowadzenia przedsiębiorstwa zgodnie z przyjętą koncepcją oraz stała pomoc i poradnictwo. Kompletna koncepcja przedsiębiorstwa obejmuje taki sposób prowadzenia przedsiębiorstwa we wszystkich jego aspektach, który pozwoli osiągnąć sukces. Proces wprowadzenia i szkolenia

1 Subfranczyzer jest reprezentantem franczyzera na swoim terenie.

2 Subfranczyzing - franczyzodawca sprzedaje franczyzobiorcy prawo do otwierania jednostek systemu na własną rękę, jak również do zawierania umów na indywidualną franczyzę z osobami trzecimi na określonym obszarze. 
polega na przeszkoleniu franczyzobiorcy w zakresie metod, których znajomość jest niezbędna do prowadzenia przedsiębiorstwa zgodnie z wzorcem. Stała pomoc i poradnictwo to przede wszystkim działalność doradcza w zakresie zarządzania i rachunkowości, promocja marki, marketing międzynarodowy oraz pomoc w zarządzaniu stroną WWW (Mendelsohn, Acheson, 1992, s. 14).

Pierwszym sklepem w Polsce działającym na zasadach franczyzy był sklep francuskiego przedsiębiorstwa kosmetycznego Yves Rocher. Sklep mieścił się przy ul. Chmielnej w Warszawie. Został założony w 1990 roku i od tego roku datuje się rozwój franczyzy w Polsce. Obecnie na terenie Polski funkcjonuje blisko 640 sieci franczyzowych, co przekłada się na blisko 20000 jednostek franczyzowych zatrudniajacych ponad 200 tysięcy osób rocznym obrotem oscylującym wokół poziomu 19 mld USD ${ }^{3}$. Jest to dowód na to, iż systemy franczyzowe rozwijają się w Polsce bardzo dynamicznie.

\section{Yves Rocher jako przykład internacjonalizacji przedsiębiorstwa poprzez franczyzę}

\subsection{Historia i ogólna charakterystyka przedsiębiorstwa}

„Marka Yves Rocher dzisiaj to ponad 30 milionów klientek, w każdym wieku, które, dzięki naszym produktom, mogą czuć się piękniejsze, a przede wszystkim akceptują siebie"4.

Yves Rocher

Yves Rocher z siedzibą w La Gacilly we Francji jest francuską firmą kosmetyczną istniejącą od ponad 50 lat. Firma powstała na bazie założonego w 1959 roku przez Yves Rochera przedsiębiorstwa produkującego kosmetyki na bazie roślin. Założeniem Yves Rochera była myśl, aby ofiarować każdej kobiecie, niezależnie od jej wieku, stylu życia czy pochodzenia bezpośredni dostęp do swoich kosmetyków. Tak powstała idea sprzedaży wysyłkowej. W 1969 r. Yves Rocher otworzył swój pierwszy sklep 5 . Obecnie ok. 35\% kapitału przedsiębiorstwa jest

3 Dane podano za: http://biznes.onet.pl/franchising-sposob-na-wlasny-biznes,18572,3227314,2, prasa-detal, [data odczytu: 2011-05-11].

4 http://www.yves-rocher.com/pl/przygoda_pewnego_wizjonera/marka_o_swiatowym_sukcesie.html, [data odczytu: 2011-02-06].

5 http://www.yves-rocher.com/pl/przygoda_pewnego_wizjonera/yves_rocher_przedsiebiorca_ wizjoner.html, [data odczytu: 2011-02-06]. 
w rękach grupy Yves Rocher, 65\% posiada Sanofi, „spółka-córka” Elf Aquitaine, której produkcja kosmetyków stanowi 1/4 całkowitych obrotów 6 .

Filozofią przedsiębiorstwa jest zagwarantowanie każdej kobiecie?:

- skutecznych, tworzonych według najnowocześniejszych metod kosmetyków,

- bezpieczeństwa i jakości,

- pełnego poszanowania zasad podjętych przez firmę w zakresie trwałego rozwoju,

- bliskiej znajomości potrzeb i pragnień kobiet,

- produktów w przystępnych cenach.

W trosce o jakość produktów Yves Rocher wybrał niezależność. W przeciwieństwie do zasad ówczesnego rynku, postawił sobie za cel całkowitą kontrolę nad produkcją swoich kosmetyków, od rośliny aż po zastosowanie kosmetyku na skórze: zaopatrywanie się w surowce naturalne, poszukiwania w świecie roślin, koncept produktu, produkcję, dystrybucję.

Działalność przedsiębiorstwa opiera się na 4 założeniach:

- podkreśleniu indywidualizmu każdej kobiety,

- innowacyjności,

- łączeniu urody z ekologią oraz redukowaniu kosztów na opakowanie i reklamę,

- odpowiadaniu na potrzeby kobiet dotyczące piękna.

Według World Panel Beaty marka Yves Rocher jest nr 1 we Francji w pielęgnacji twarzy, pielęgnacji ciała oraz w makijażu ${ }^{8}$. Sprzedaż marki Yves Rocher oscyluje wokół 2.7 miliona USD.

\subsection{System działania systemu franczyzowego Yves Rocher na świecie}

Yves Rocher sprzedaje swoje produkty franczyzobiorcom ze średnim rabatem $30 \%$ od zalecanych cen sprzedaży VAT, które publikuje w swoich katalogach. Yves Rocher podpisuje umowę z franczyzobiorcami biorąc pod uwagę ich osobowość, ewidentne zdolności do prowadzenia sprzedaży detalicznej kosmetyków i wyniki programu treningowego. Po podpisaniu umowy franczyzobiorca zobowiązuje się do zatrudnienia w swoim Centrum wystarczającej liczby wykwalifikowanych pracowników ${ }^{9}$.

6 [Decyzja Komisji Europejskiej z dnia 17 grudnia 1986 r. w sprawie zastosowania art. 85 Traktatu EWG].

7 http://www.yves-rocher.com/pl/nasza_wizja_piekna/odkryj_siebie_na_nowo.html, [data odczytu: 2011-02-06].

8 Yves Rocher, Zielona Księga Urody 2011, s. 3.

9 Zob. Decyzja Komisji Europejskiej z dnia 17 grudnia 1986 r. 
Franczyzobiorcy marki Yves Rocher są właścicielami swoich przedsiębiorstw, które prowadzą na własne ryzyko. Ponoszą koszty wyposażenia swoich lokali zgodnie z projektem i specyfikacją otrzymaną od Yves Rocher. Przedsiębiorstwo Yves Rocher przyznaje franczyzobiorcy wyłączne prawo używania oznaczeń identyfikujących franczyzodawcę oraz know-how dotyczące sprzedaży jego produktów $\mathrm{w}$ punkcie sprzedaży detalicznej na terytorium określonym $\mathrm{w}$ umowie. Yves Rocher zachowuje również prawo sprzedaży swoich produktów konsumentom innymi metodami, szczególnie metodą wysyłkową ${ }^{10}$. Know-how, które Yves Rocher zobowiązuje się przekazać franczyzobiorcy zawiera wszelkie aspekty działalności franczyzowej, a w szczególności aspekty techniczne, handlowe, promocyjne, reklamowe, administracyjne i finansowe ${ }^{11}$.

We wszystkich krajach franczyzobiorca wnosi wstępną opłatę licencyjną. W Holandii, oprócz wstępnej opłaty licencyjnej, franczyzobiorca wnosi opłatę w wysokości 1\% swoich obrotów netto, wyłączając z tego obroty związane z usługami kosmetycznymi. Franczyzobiorca płaci Yves Rocher w regularnych odstępach czasu ustalony procent kosztów reklamy. Jest on również zobowiązany przedkładać franczyzodawcy do wcześniejszego zatwierdzenia wszelkie formy reklamy i promocji, które chce przedsięwziąć na własny rachunek. W tym przypadku Yves Rocher kontroluje jedynie charakter reklamy, a nie podane w niej ceny sprzedaży detalicznej. Yves Rocher zachowuje prawo kontroli wielkości zapasów oraz otrzymywania od franczyzobiorcy kopii rachunków i bilansu księgowego ${ }^{12}$.

W celu uproszczenia złożonego systemu franczyzowego przedsiębiorstwo Yves Rocher opublikowało broszurę, gdzie w sposób przejrzysty przedstawia cały proces franczyzowy. Przed otworzeniem sklepu, kandydat na franczyzobiorcę przechodzi przez wstępny program treningowy (franc. Franch'yr) podzielony na dwie części:

- tygodniowe szkolenie teoretyczne,

- tygodniowe szkolenie praktyczne w jednym ze sklepów Yves Rocher.

Celem szkolenia jest zaznajomienie potencjalnego kontrahenta $\mathrm{z}$ koncepcją prowadzenia sklepu Yves Rocher, zdobycie wiedzy na temat technik sprzedaży oraz oferty produktowej, zapoznanie ze specyfiką branży kosmetycznej oraz zdobycie umiejętności obsługi kasy fiskalnej.

Kolejny program treningowy (franc. Découvr'yr) przewidziany jest już dla personelu sklepu. Głównym celem tego szkolenia jest zapoznanie pracowników $\mathrm{z}$ wartością marki oraz zaznajomienie $\mathrm{z}$ technikami sprzedaży bezpośredniej ${ }^{13}$.

10 Zob. Decyzja Komisji Europejskiej z dnia 17 grudnia 1986 r.

11 Ibidem.

12 Ibidem.

$13 \mathrm{http} / / /$ www.yvesrocherpromo.ca/franchise/YR_franchise_en.pdf, ulotka Yves Rocher, Determine your future...naturally, Become an Yves Rocher franchisee, [data odczytu: 2011-02-08]. 
Franczyzobiorcy nie pozostają sami jeśli chodzi o marketing i wsparcie sprzedaży. Zgodnie z informacjami zawartymi w ulotce Determine your future...naturally, Become an Yves Rocher franchisee, każdy franczyzobiorca otrzymuje:

- scenariusz działań, który dostarcza informacji na temat comiesięcznych planów promocji tworzonych na potrzeby danej marki;

- $\quad$ pomoc w aranżacji wystawy sklepowej, zmienianej co 17 dni, 21 razy w ciągu roku;

- Zieloną Księgę Urody - dostępną w 20 wersjach językowych, stanowiącą ofertę produktową i łącznik pomiędzy marką a Klientem, w chwili obecnej produkuje się ok. 20 milionów egzemplarzy rocznie;

- kartę stałego klienta oraz program lojalnościowy;

- personalizowany e-mailing - informujący o nowościach, promocjach oraz ofertach specjalnych.

\subsection{Charakterystyka systemu franczyzowego Yves Rocher w Polsce}

Pod marką Yves Rocher kryją się naturalne, oparte na wyciągach roślinnych, nietestowane na zwierzętach i przede wszystkim przystępne cenowo produkty. Dzięki temu sieć sklepów w których sprzedawane są wyłącznie kosmetyki Yves Rocher powiększa się z roku na rok. Sklepy te, często połączone z firmowymi gabinetami kosmetycznymi, są obecne w największych miastach w Polsce. Yves Rocher Polska oferuje pomoc w zakresie przygotowania sklepu do otwarcia, dostarcza materiały promocyjne i umożliwia bezpłatne szkolenia personelu.

Tabela 3. Założenia systemu franczyzowego Yves Rocher w Polsce

\begin{tabular}{|c|c|c|c|}
\hline $\begin{array}{c}\text { Czas trwania } \\
\text { umowy }\end{array}$ & $\begin{array}{c}\text { Pozafinansowe wymagania } \\
\text { franczyzodawy w stosunku } \\
\text { do franczyzobiory }\end{array}$ & $\begin{array}{l}\text { Zobowiązania } \\
\text { franczyzodawcy }\end{array}$ & Opłaty \\
\hline $\begin{array}{l}3 \text { lata } \\
\text { z możliwością } \\
\text { przedłużenia }\end{array}$ & 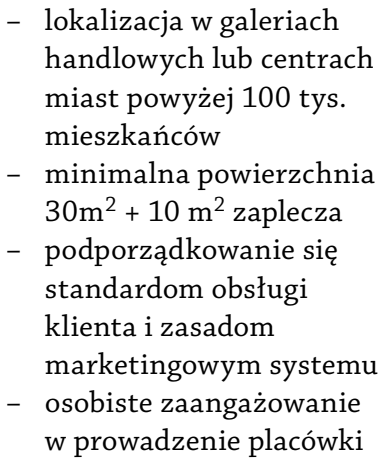 & $\begin{array}{l}\text { - } \text { pomoc } \\
\text { w przygotowaniu } \\
\text { sklepu do otwarcia, } \\
\text { - } \text { materiały } \\
\text { reklamowe } \\
\text { i promocyjne } \\
\text { - } \text { sieciowy program } \\
\text { lojalnościowy } \\
\text { - } \text { szkolenia personelu } \\
\text { w zakresie } \\
\text { sprzedaży } \\
\text { asystowanej }\end{array}$ & $\begin{array}{l}\text { - wstępna: brak } \\
\text { danych } \\
\text { - bieżąca: w cenie } \\
\quad \text { towaru } \\
\text { Przewidywana kwota } \\
\text { inwestycji: } 110 \text { tys. } \\
\text { PLN }\end{array}$ \\
\hline
\end{tabular}

Źródło: opracowanie własne na podstawie: Ziółkowska (2010, s. 224). 
Zgodnie z tabelą 3 do podstawowych wymagań sieci należą ${ }^{14}$ :

- lokal z witryną w centrach handlowych lub przy głównych ulicach handlowych miast przekraczających 100 tys. mieszkańców;

- minimalna powierzchnia sprzedaży $-30 \mathrm{~m}^{2}+10 \mathrm{~m}^{2}$ zaplecza $+10 \mathrm{~m}^{2}$ jeśli biorca planuje prowadzenie $\mathrm{w}$ ramach działalności również gabinetu kosmetycznego;

- podporządkowanie się standardom obsługi klienta i zasadom związanym z działaniami marketingowymi, jednolitymi w całej Polsce.

Reasumując, Yves Rocher Polska Sp. z o.o. oferuje pomoc w zakresie przygotowania sklepu do otwarcia, dostarcza materiały promocyjne i umożliwia bezpłatne szkolenia personelu ${ }^{15}$. W Polsce koncern Yves Rocher posiada łącznie 98 sklepów własnych (m.in.: Warszawa, Kraków, Łódź, Gdańsk, Poznań, Bydgoszcz, Szczecin, Radom, Zabrze, Bielsko-Biała, Mikołów, Katowice) oraz sklepów prywatnych (biorców licencji). Oprócz kosztów związanych z przystosowaniem lokalu do prowadzenia działalności, wkład kapitałowy biorcy określa się na około 110 tys. zł netto (meble + pierwsze zatowarowanie sklepu).

\section{Zakończenie}

Przedsiębiorstwo Yves Rocher działa obecnie w 54 krajach na kilku kontynentach, posiada 1500 sklepów i zatrudnia ponad 15 tys. osób. Jest jedną z największych sieci franczyzowych na świecie i pierwszą, która weszła na rynek polski.

Można więc przyjąć za prawdziwą tezę, że w przypadku przedsiębiorstwa Yves Rocher mamy do czynienia $z$ franczyzą globalną ${ }^{16}$, ponieważ powiązania franczyzowe obejmują wiele krajów (wiele kontynentów) i charakteryzują się strategią ekspansji geograficznej.

\section{Bibliografia}

Abell, M. (1990), The international franchise option, Waterlow Publisher, London. Gorynia, M. (2007), Strategie zagranicznej ekspansji przedsiębiorstw, Polskie Wydawnictwo Ekonomiczne, Warszawa.

14 http://www.yvesrocherpromo.ca/franchise/YR_franchise_en.pdf, ulotka Yves Rocher, Determine your future...naturally, Become an Yves Rocher franchisee, [data odczytu: 2011-02-08].

15 http://www.yves-rocher.com.pl/jak_zostac_naszym_partnerem, [data odczytu: 2011-02-08].

16 Franczyza globalna jest rozszerzoną formą franszyzy międzynarodowej (Zob. Ziółkowska, 2010, s. 42). 
Grabowski, M. (1998), Franchising w Polsce: sposób na ekspansję polskich i zagranicznych przedsiębiorstw?, Instytut Badań nad Gospodarką Rynkową, Gdańsk.

Kolarski, G. (1992), Franchising, Centrum Informacji Menedżera, Warszawa.

Leontiades, J.C. (1985), Multinational Corporate Strategy, D.C. Health, Lexington.

Mendelsohn, M., Acheson, D. (1992), Franchising, Poltext, Warszawa.

Murray, I. (2008), Przewodnik po franczyzie: jak wybrać najlepszq dla Twojego biznesu?, Helion, Gliwice.

Pietrasieński, P. (2005), Międzynarodowe strategie marketingowe, Polskie Wydawnictwo Ekonomiczne, Warszawa.

Rymarczyk J. (2004), Internacjonalizacja i globalizacja przedsiębiorstw, Polskie Wydawnictwo Ekonomiczne, Warszawa.

Rymarczyk, J., Szeląg, T. (2001) (red.), Internacjonalizacja i globalizacja gospodarki polskiej, Wydawnictwo Akademii Ekonomicznej im. Oskara Langego we Wrocławiu, Wrocław.

Yves Rocher, Zielona Księga Urody 2011.

Ziółkowska, M., Franczyza. Nowoczesny model rozwoju biznesu, Cedewu, Warszawa 2010.

\section{e-źródła}

Czubała, A., Jonas, A., Smoleń, T. (2005), Internacjonalizacja usług w Polsce, „Zeszyty Naukowe Akademii Ekonomicznej w Krakowie" nr 677, Kraków.

Steinerowska-Streb, I., Franchising $w$ rozwoju matych i średnich przedsiębiorstw Polsce, „Ekonomika i Organizacja Przedsiębiorstwa” 5/2003.

Yves Rocher, Determine your future naturally, Determine your future...naturally, Become an Yves Rocher franchisee,

http://www.yvesrocherpromo.ca/franchise/YR_franchise_en.pdf

\section{Akty prawne}

Decyzja Komisji Europejskiej z dnia 17 grudnia 1986r W sprawie zastosowania art. 85 Traktatu EWG. (IV/31.428 do 31.432- Yves Rocher) ( 87/14/EWG) (Official Journal 1987, L 8)

\section{Witryny internetowe}

http://www.yves-rocher.pl/

http://profitsystem.pl

http://franchising.pl

http://www.franczyzawpolsce.pl

http://biznes.onet.pl

http://www.happi.com/articles/2010/08/9-yves-rocher 


\section{Summary}

\section{Yves Rocher Company as Example of Internationalization Through Franchising}

The article discusses franchising as a method of internationalization. Based on the theory, the author shows a practical approach to franchising through a real case study. The theoretical part touches on different forms of internationalization and also on basic foundation of franchise system. In the empirical part the author briefly characterizes the Yves Rocher company and their influence on the franchise system.

Key words: franchising, franchisor, internationalization, Yves Rocher.

\section{Резюме}

\section{Интернационахизация предприятия путем франшизы на примере Yves Rocher}

Статья показывает франшизу как форму интернационализации предприятий на примере французского косметического предриятия Yves Rocher. B теоретичесой части статьи представлены формы и виды интернационализации предприятий, а также охарактеризованы основные положения франшизной системы. Главной формой высказывания, примененной в этой части статьи, является изложение. Это форма описания, обеспечивающая точную передачу мыслей, содержащихся в первоисточниках. В эмпирической части работы проводится синтетический анализ концерна Yves Rocher, вытекаюший из хода проводимых теоретических рассуждений, касающихся франшизной системы.

Ключевые слова: франшиза, интернационализация, Yves Rocher.

\section{Mgr Alina Jamróz-Ligęza}

Absolwentka Uniwersytetu Ekonomicznego w Krakowie na kierunku stosunki międzynarodowe $\mathrm{w}$ zakresie zarządzania międzynarodowego oraz Uniwersytetu Jagiellońskiego na kierunku kulturoznawstwo w zakresie amerykanistyki. Absolwentka studiów doktoranckich na Uniwersytecie Ekonomicznym 
w Krakowie. Kierownik Projektu POKL EFS w organizacji pozarządowej. Zainteresowania naukowe to: struktury klastrowe, kooperencja, internacjonalizacja przedsiębiorstw, kulturowe aspekty zarządzania, style kierowania, historia polityki kolonialnej Anglii i Hiszpanii na kontynencie północnoamerykańskim oraz wyspach Morza Karaibskiego. 